А. Росохата, Н. Летуновська, В. Макерська, В. Кропива

Поведінка споживачів у цифровому середовищі під впливом пандемії COVID-19: ...

УДК 330.544.2:339.138

JEL classification: D11, I12, M31

DOI: https://doi.org/10.35774/visnyk2021.03.098

\title{
Анна POCOXATA,
}

кандидат економічних наук, кафедра маркетингу,

Сумський державний університет,

вул. Римського-Корсакова, 2, м. Суми, 40007, Україна, e-mail: a.rosokhata@kmm.sumdu.edu.ua

ORCID ID: https://orcid.org/0000-0001-6944-1515

Наталія ЛЕТУНОВСЬКА,

кандидат економічних наук, доцент, кафедра маркетингу,

Сумський державний університет,

вул. Римського-Корсакова, 2, м. Суми, 40007, Україна,

e-mail: n.letunovska@kmm.sumdu.edu.ua

ORCID ID: https://orcid.org/0000-0001-8207-9178

\section{Вікторія МАКЕРСЬКА,}

аспірант кафредри маркетингу, Сумський державний університет,

вул. Римського-Корсакова, 2, м. Суми, 40007, Україна,

e-mail:v.makerska@kmm.sumdu.edu.ua

ORCID ID: https://orcid.org/0000-0001-6628-8623

\section{Вячеслав КРОПИВА,}

студент ННІ БіЕМ, Сумський державний університет, вул. Римського-Корсакова, 2, м. Суми, 40007, Україна, e-mail: kropuvavyacheslav@gmail.com

ORCID ID: https://orcid.org/0000-0002-6739-5276

\section{ПОВЕДІНКА СПОЖИВАЧІВ У ЦИФРОВОМУ СЕРЕДОВИЩІ ПІД ВПЛИВОМ ПАНДЕМІЇ COVID-19: ВАЖЛИВІСТЬ ФАКТОРУ ЗДОРОВ'Я ТА ТРАНСПАРЕНТНОСТІ БІЗНЕСУ}

Росохата А., Летуновська Н., Макерська В., Кропива В. Поведінка споживачів у цифровому середовищі під впливом пандемії COVID-19: важливість фрактору здоров'я та транспарентності бізнесу. Вісник економіки. 2021. Вип. 3. C. 98-109. DOI: https://doi. org/10.35774/visnyk2021.03.098

Rosokhata, A., Letunovska, N., Makerska V., Kropyva V. (2021). Povedinka spozhyvachiv u tsyfrovomu seredovyshchi pid vplyvom pandemiii COVID-19: vazhlyvist faktoru zdoroviia ta transparentnosti biznesu [Consumer behavior in the digital environment under the influence of the COVID-19 pandemic: the importance of the health factor and business

(c) Анна Росохата, Наталія Летуновська, Вікторія Макерська, Вячеслав Кропива, 2021. 
transparency]. Visnyk economiky - Herald of Economics, 3, 98-109. DOI: https://doi. org/10.35774/visnyk2021.03.098

\section{Анотація}

Bступ. 3 початком карантину, спричиненого пандемією COVID-19, очевидними $\epsilon$ зміни в поведінці споживачів, що полягають у зростанні паніки та більш свідомої поведінки з акцентуванням уваги на власному здоров'ї та уникненні можливих загроз. Тому дослідження поведінки споживачів у таких умовах є актуальним та своєчасним завданням.

Mema. Мета дослідження полягає в аналізі змін поведінки споживачів у цифровому середовищі під впливом подій, спричинених пандемією COVID-19.

Метод (методологія). Теоретико-методологічною основою дослідження стали загальнонаукові методи наукового пізнання: теоретичного узагальнення, систематизації, аналізу та синтезу. Автори дослідили тенденції споживчої поведінки в умовах пандемії COVID-19. Проаналізовано основні стадії зміни споживчої поведінки. Виокремлено етапи переходу компаній до комунікацій зі споживачами в цифровому середовищі. Визначено, що піклування про здоров'я та відкритість компанії (транспарентність бізнесу) є визначальними чинниками, що формують ступінь довіри до суб'єктів господарювання у посткризовий період. Наведена коротка статистика щодо світового споживання продуктів різних сорер, зокрема виявлена позитивна динаміка зростання кількості пошукових запитів користувачів Інтернету щодо покупки продукції в сфрері здоров'я. Зроблено порівняння кількості пошукових запитів у сервісі Google Trends для термінів «доставка продуктів» та «здоров'я» у межах ринку України та у світі. Визначено, що популярності набуває новий напрямок просування «маркетинг із уст в уста», що є ефективним інструментом комунікацій зі споживачами в цифровому середовищі за допомогою соціальних мереж та різних майданчиків кіберпростору.

Результати. Визначено основні тренди інтернет-маркетингу останніх років та сформовано рекомендації щодо наповненості маркетинговими інструментами майбутніх стратегій компаній у цифровому середовищі. Висновки роботи можуть бути корисними спеціалістам сфери просування продуктів у мережі Інтернет, а також практикуючим маркетологам у сфрері інноваційних сервісів, що набувають популярності на хвилі світових тенденцій зміни споживчої поведінки.

Перспективи. У подальших наукових розробках доцільно зосередити увагу на кількісних маркетингових дослідженнях ставлення споживачів до продуктових пропозицій компаній та їхньої готовності до співпраці, підкріплених розробленими маркетинговими програмами.

Ключові слова: відкритість бізнесу, здорова поведінка, маркетинг «із уст в уста», маркетингова стратегія, тренди.

Формули: 0; рис.: 3; табл.: 1; бібл.: 16.

\section{Anna ROSOKHATA,}

PhD. (Economics), Department of Marketing Sumy State University, 2 Rymskyi-Korsakiv street, Sumy, 40000, Ukraine, 
e-mail: a.rosokhata@kmm.sumdu.edu.ua

ORCID ID: https://orcid.org/0000-0001-6944-1515

\title{
Nataliia LETUNOVSKA,
}

PhD. (Economics), Associate Professor,

Department of Marketing, Sumy State University, 2 Rymskyi-Korsakiv street, Sumy, 40000, Ukraine, e-mail: n.letunovska@kmm.sumdu.edu.ua

ORCID ID: https://orcid.org/0000-0001-8207-9178

Viktoriia MAKERSKA,

PhD student of the Department of Marketing,

Sumy State University,

2 Rymskyi-Korsakiv street, Sumy, 40000, Ukraine,

e-mail: v.makerska@kmm.sumdu.edu.ua

ORCID ID: https://orcid.org/0000-0001-6628-8623

\section{Viacheslav KROPYVA,}

Student, Academic and Research Institute of Business, Economics and Management,

Sumy State University,

2 Rymskyi-Korsakiv street, Sumy, 40000, Ukraine,

e-mail: kropuvavyacheslav@gmail.com

ORCID ID: https://orcid.org/0000-0002-6739-5276

\section{CONSUMER BEHAVIOR IN THE DIGITAL ENVIRONMENT UNDER THE INFLUENCE OF THE COVID-19 PANDEMIC: THE IMPORTANCE OF THE HEALTH FACTOR AND BUSINESS TRANSPARENCY}

\begin{abstract}
Introduction. With the onset of quarantine caused by the COVID-19 pandemic, changes in consumer behavior are evident, such as increased panic and more conscious behavior focusing on health and avoiding potential threats. Therefore, the study of consumer behavior in such conditions is an urgent and timely task.

Purpose. The study aims to analyze changes in consumer behavior in the digital environment under the influence of events caused by the COVID-19 pandemic.

Method (methodology). The theoretical and methodological basis of the study were general scientific methods of scientific knowledge: theoretical generalization, systematization, analysis and synthesis. The authors investigated trends in consumer behavior in the context of the COVID-19 pandemic. The main stages of change in consumer behavior are analyzed. The steps of the transition of companies to communicate with consumers in the digital environment were singled out. Factors such as health care and openness (business transparency) have been identified as determinants of trust in businesses in times of crisis. Brief statistics on the global consumption of products in various fields are presented. In particular, the positive dynamics in the growth of Internet
\end{abstract}


users' search queries for the purchase of health products are revealed. A comparison of the number of search queries in the Google Trends service for thematic terms of the research: "product delivery» and "health» within the Ukrainian market and in the world. It is determined that a new direction of word-of-mouth marketing is gaining popularity, which is an effective tool for communication with consumers in the digital environment through social networks and various cyberspace sites.

Results. The authors identify the main trends in Internet marketing in recent years and make recommendations on marketing tools for future strategies of companies in the digital environment. The findings can be helpful to experts in the field of product promotion on the Internet and practicing marketers in the area of innovative services, which are gaining popularity in the wake of global trends in consumer behavior.

Perspectives. In further research, the authors should focus on quantitative marketing research of consumers' attitudes to companies' product offerings and their willingness to cooperate, supported by the developed marketing programs.

Keywords: business openness, healthy behavior, word of mouth marketing, marketing strategy, trends.

Formulas: 0; fig.: 3; tabl.: 1; bibl.: 16 .

Постановка проблеми. Пандемія COVID-19 є глобальним викликом, який змінив і змінює споживчу поведінку в світі. Більшість споживачів перейшли в онлайнсередовище. На деякі товари попит зменшився, а на інші навпаки - збільшився. Для багатьох підприємств, які готові запропонувати свої товари та послуги в онлайн-просторі, з'явилось багато можливостей. Підприємці у цей час мають бути дуже спостережливі, адже пріоритети споживачів кожного дня змінюються. Під впливом пандемії сучасний етап розвитку цифрового середовища характеризується підвищенням конкурентної боротьби. Керівники для забезпечення розвитку визнають необхідним пошук та виокремлення чинників, які найбільшою мірою вплинуть на конкурентоспроможність. Якщо раніше споживачі здебільшого фокусувалися на якості та ціні товару або послуги, то сьогодні до цих чинників додалися вплив на екологію, цінності компанії-виробника, рівень «здоровості» продукту (кількість та відновність ресурсів, що були використані при його виробництві, їх походження), корисність від споживання, можливість оздоровлення в результаті використанні продукту (якщо мова йде про спеціалізовані товари та сервіси). До переліку вказаних чинників також входить транспарентність (прозорість компанії) - сукупність комунікацій між керівництвом компанії, з одного боку, та суспільством, ЗМІ - з іншого. Прозорість компанії визначають тією специфічною характеристикою, яка впливає на обсяги споживання. Транспарентність увійшла до трійки ключових цінностей, якими, на думку споживачів, повинна володіти сучасна компанія [1]. Тобто, якщо прозорість $€$ цінністю для споживачів, то компанії мають брати до уваги такий чинник, щоб займати конкурентну позицію у цифровому середовищі. Уже відомі додатки, які допомагають вибирати товари за прозорістю ведення бізнесу (GoodGuide, Shop Ethical, Skytruth) [1]. Упродовж 2020 - початку 2021 р. стало зрозуміло, що рух у бік соціально та еколого свідомого споживання, який спостерігався і до початку пандемії COVID-19, набирає неабияких обертів. Люди дедалі більше піклуються про власне здоров'я, особистий 
добробут та суспільство і світ навколо. Новий стиль життя змінив споживчий ринок. Зростає споживчий попит на корисні для здоров'я продукти, а також покупці очікують більшої прозорості та екологічності на всіх етапах виробництва та збуту продуктів. Дослідження [2], проведене в березні 2021 р., показало, що половина респондентів включає до свого раціону більше рослинних продуктів з метою формування більш сприятливого для довкілля раціону харчування. Означені вище чинники зумовили актуальність дослідження та визначили його мету та основні завдання.

Аналіз останніх досліджень і публікацій. Змінуповедінки споживачів у цифровому середовищі під впливом подій, викликаних COVID-19, досліджено в наукових працях О. А. Небилиці [3], К. О. Латишева, В. В. Герасимчук [4], О. М. Вовчанської, Л. О. Іванової [5], Л. В. Боровик [6], Н. В. Проскруніної [7], 3. М. Андрушкевич, В. М. Нянько, О. В. Сітарчук [8], В. Бороноса, О. Захаркіна, О. Захаркіної, Ю. Білоус [9]. Сучасні інструменти маркетингу в сфрері роботи зі споживачами та впливу на їхню поведінку досліджено в працях Ю. М. Мельник, Л. Ю. Сагер, І. Ю. Черкас [10], Л. О. Сигиди [11], Л. М. Хоменко [12], 3. Гончарової, Я. Пітекової, М. Враблікової [13], V. Davidaviciene, I. Meidute-Kavaliauskiene, R. Paliulis [14]. Незважаючи на вагомість цих досліджень, наукова важливість зміни поведінки споживачів у період карантину все ще актуальна.

Мета дослідження полягає в аналізі змін поведінки споживачів у цифровому середовищі під впливом подій, спричинених пандемією COVID-19.

Виклад основного матеріалу дослідження. Багато споживачів сьогодні віддають перевагу продуктам, які вироблені з місцевих інгредієнтів, через їхню корисність для екології та суб'єктивну цінність для споживачів як щось «рідне, не привозне». Ринок стає все більш персоналізованим з перманентним збором даних та відстеженням поведінки споживачів. В ідеалі компанії прагнуть запропонувати кожному покупцеві індивідуально розроблений процес покупки, для чого споживачі повинні пройти опитування щодо власного стану здоров'я та прийнятного для них раціону харчування / розпорядку дня (якщо аналізуємо клієнтів компанії, що є провайдером певних послуг). Якщо споживач не хоче бачити продукти, які містять, наприклад, яєчні продукти, то вони отримують власну, автоматично підібрану саме для них вітрину продуктів, що відповідає їхнім потребам та запитам.

Доречно зазначити, що в світовому масштабі сьогодні на ринку розвивається новий тип споживачів. Вони стикаються з фінансовими труднощами, активно використовують цифрові технології, а також довго обдумують ухвалення своїх купівельних рішень. 3 їхнього боку змінюється зміст довіри до компанії. Раніше довіра означала те, що бренд виконує всі обіцянки. Тепер під нею розуміють пріоритет потреб клієнтів: відчуття ним безпеки, корисність продукту, збереження особистих даних, які повинні бути захищені. 3 цих позицій компанії мають більше зосереджуватися на цифровій підтримці своїх споживачів, а також чітко розуміти, як вони в майбутньому будуть закріплювати довіру до свого бренда.

Під час пандемії безконтактні платежі та онлайн-покупки стали звичною справою для основної маси споживачів, адже відвідування фізичних магазинів скоротилося. Якщо до пандемії 2020 р. покупкам офрлайн надавало перевагу приблизно 35-40\% споживачів, то в 2021 р. - 25\%. Багато споживачів купують продукти в інтернетмагазинах, а також вони використовують продукцію місцевих виробників, а не відомі 
світові бренди. Через необхідність працювати вдома онлайн зріс попит на програми, які організовують конференц-зв'язок: Zoom, Hangouts Meet від Google. Крім цього, збільшилася популярність сервісів, які дозволяють працювати з великими обсягами даних (наприклад, Amazon Web Services). У ході дослідження виокремлено шість стадій зміни споживчої поведінки (табл. 1).

Таблиця 1

\section{Стадії змін поведінки споживачів під час кризових явищ, що становлять загрозу для здоров'я}

\begin{tabular}{|c|c|}
\hline Стадія & Характеристика стадії \\
\hline Перша & $\begin{array}{c}\text { Споживачі купують та використовують продукти, які допомагають підтримувати } \\
\text { імунітет (вітаміни, корисні харчові добавки, фітнес-заняття тощо) }\end{array}$ \\
\hline Друга & $\begin{array}{c}\text { Споживачі звертають увагу на товари, які спроможні знизити ризик зараження } \\
\text { (дезінфектанти, маски для обличчя) }\end{array}$ \\
\hline Третя & $\begin{array}{c}\text { Активна підготовка до карантину: закупівля найнеобхіднішого (крупа, чай, олія, } \\
\text { засоби для подолання застуди, товари особистої гігієни). Стадія характерна } \\
\text { збільшенням споживчих кошиків }\end{array}$ \\
\hline Четверта & Споживачі перебувають вдома, активізуються онлайн-покупки \\
\hline П'ята & У зв'язку з підвищенням цін та дефріцитом різних груп товарів споживачі стають \\
більш чутливими до цін
\end{tabular}

Джерело: розроблено авторами.

Період 2020-першого кварталу 2021 р. характеризувався 8\% зростанням активності користувачів у соціальних мережах. На 6\% зросла активність у сегменті громадського харчування та доставки. На 20\% збільшилась зацікавленість в інфрормації щодо сфери управління. На 10\% зріс графрік на стрімінгових ресурсах. Водночас зацікавленість медіа-ресурсами зросла від початку карантину.

Зростання попиту на послуги компаній з доставки продуктів можна простежити за динамікою запитів у Google Trends. Наприклад, аналіз за пошукових запитом Glovo дав такі результати (рис. 1). Аналіз запитів упродовж останніх п'яти років показав неабияке зростання їхньої популярності саме в 2020 р. з піком на етапі жорстких карантинних заходів для протистояння поширенню коронавірусу. Урядові заходи в поєднанні 3 прагненням людей підтримати своє здоров'я та здоров'я своїх близьких спонукали їх залишатися вдома та надавати перевагу сервісам з доставки (наприклад, Glovo).

Кількість пошукових запитів «Доставка продуктів» серед користувачів з України значно зросла в 2020 р. (рис. 2). Якщо аналізувати масштаби пошукових запитів за словом «health» у сфрері покупок, то відмітною $є$ та сама тенденція щодо зростання їхньої кількості в середині 2020 р. з поступовою стабілізацією до 2021 р. (рис. 3).

Сьогодні аудиторія повертається до звичайного ритму життя, проте адаптує свої вподобання та звички до поведінки в онлайн-середовищі, адже зростає популярність таких видів кібер-діяльності, як онлайн-екскурсії, онлайн-тренінги, онлайн-спорт тощо. Компанії, які спроможні краще задовольнити потреби своїх споживачів новими способами, у майбутньому зможуть не лише здобути лояльних клієнтів, а й вийти 3 карантинного режиму із відчутним поповненням бази клієнтів. Для цього їм необхідно удосконалювати параметри свого сервісу та активізувати маркетингові активності. 


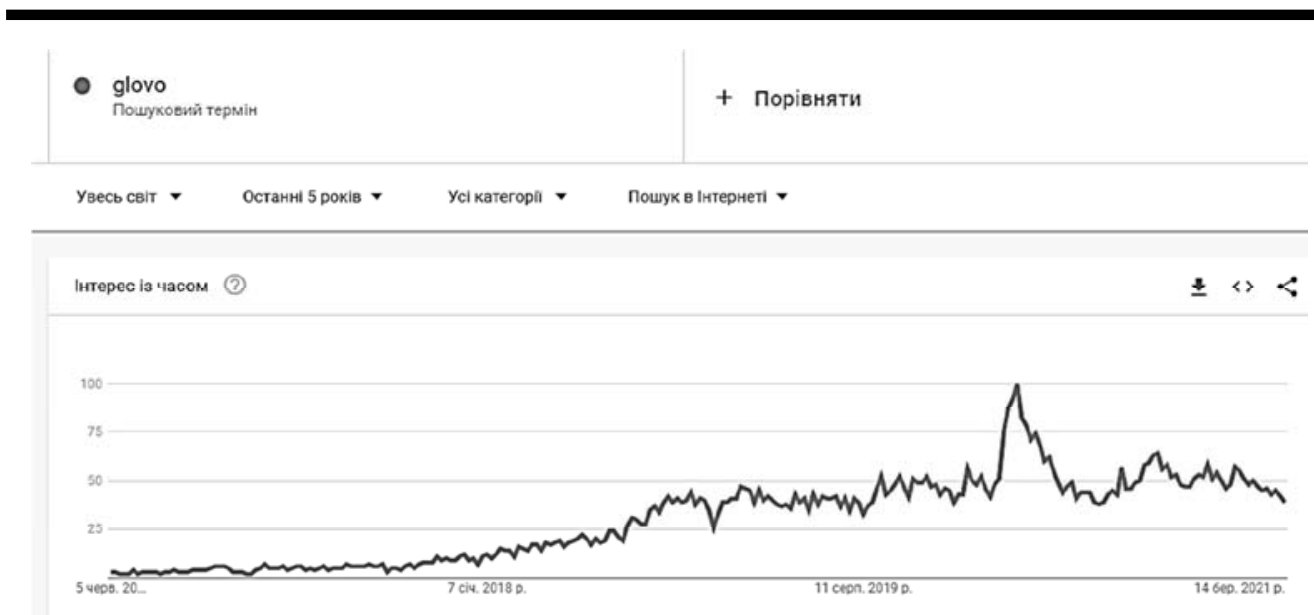

Рис. 1. Статистика попиту на бренд Glovo у сервісі Google Trends

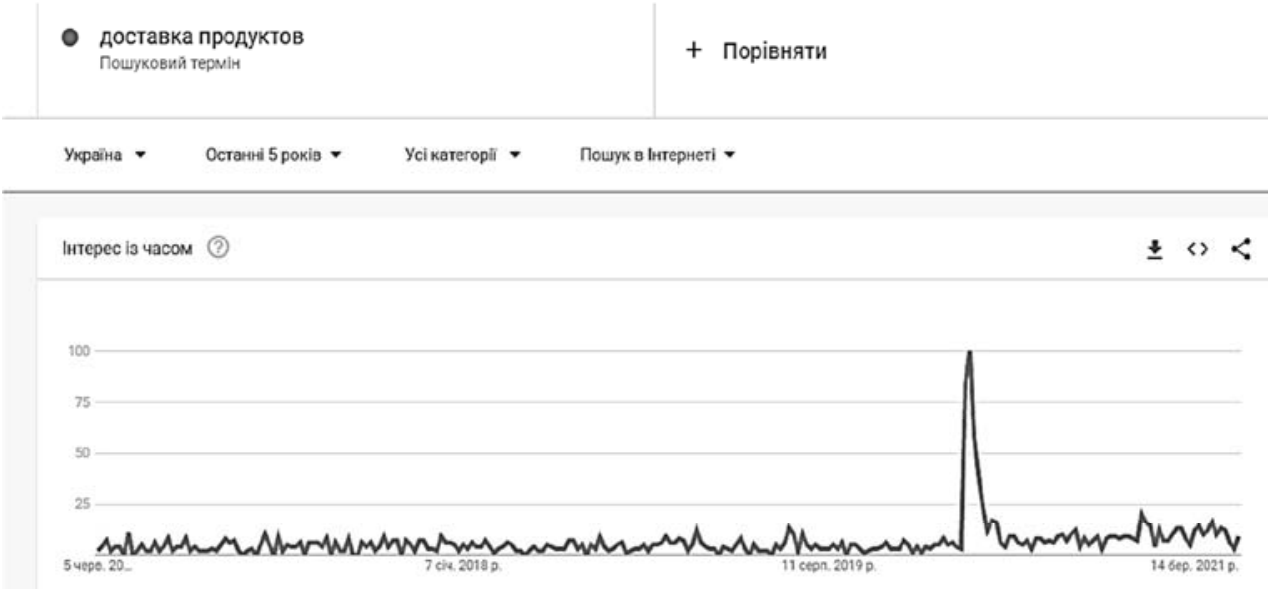

Рис. 2. Статистика популярності пошукового запиту «доставка продуктов» серед інтернет-користувачів з України у Google Trend

В умовах пандемії карантин та необхідність дотримання соціальної дистанції примусили споживача змінити підхід до здійснення покупок. Перед маркетологами з'явилася складна ціль щодо переосмислення стратегії компанії, а також щодо способу роботи зі споживачами [15]. Для охоплення уваги клієнтів насамперед необхідний якісний онлайн-контент та правильне врахування того, у якому інфрормаційному просторі знаходиться цільова аудиторія кожного окремого проєкту. Якщо ще кілька років тому соціальні медіа більшість користувачів використовували для спілкування 3 друзями, то тепер вони перетворилися на платформу, де $є$ бізнес, де приватні особи можуть обмінюватися ідеями. Це було чітко видно під час пандемії, коли багато організацій масово переходили до своїх профрілів або почали створювати їх у різних соціальних мережах та на різних сайтах. 


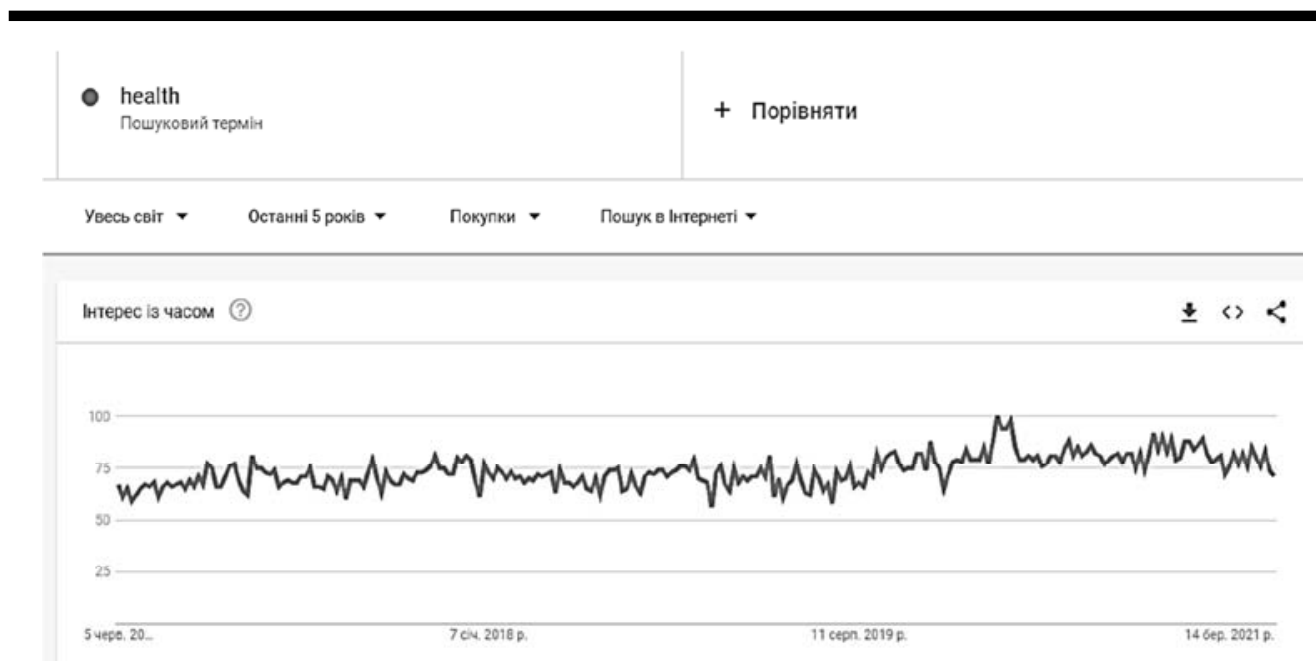

Рис. 3. Статистика популярності пошукового запиту «health» у категорії «Покупки» серед інтернет-користувачів у сервісі Google Trends

Збільшення кількості інтернет-користувачів та зниження витрат на залучення клієнтів у цифровому середовищі змушують бізнес трансформувати маркетингові стратегії в онлайн-просування, у якому головна увага має бути приділена користувачеві. Криза дає змогу компаніям дефіцитних ніш отримати миттєві вигоди. Проте в довгостроковій перспективі такий підхід може завершитися формуванням негативної репутації. У рамках довгострокових стратегії той, хто використовує час самоізоляції на налаштування контакту з користувачами, піклується про соціальну відповідальність бізнесу, його транспарентність, розвиває соціальну комерцію та враховує тренди на здоровий спосіб життя, може підвищити свою конкурентоспроможність, створивши лояльну базу клієнтів. Крім того, важливо пам'ятати, що конкуренція в онлайн-середовищі відбувається не зі звичайними опонентами за тематикою, а 3 інноваційними публічними товариствами. Основним форматом споживання контенту в онлайн є стрічка новин, тому великої значущості набуває якість присутності компанії в інформаційному полі споживачів. У цифровому середовищі компаніям варто інвестувати в онлайн-присутність. Але однієї присутності замало: потрібно робити їі ефективною. Тому необхідно інвестувати в онлайн-репутацію, тобто лайки, онлайнвідгуки, репости - те, що узагальнюється поняттям «маркетинг із уст в уста».

Крім цього, доречно, щоб компанії забезпечили можливості для зворотної комунікації зі споживачами, зокрема роботу з позитивними та негативними відгуками. Перевагою буде те, що вони зможуть дізнатися можливі проблеми, виправити їх та зробити кращим особистий імідж. Це рішення не тільки блокуватиме негативне обговорення компанії з близькими, а й покращить репутацію компанії. Отримуючи відгуки, компанія має можливість швидко втілити різні цікаві пропозиції у життя, отримавши переваги.

У час кризи краще не тільки підтримувати розмову з клієнтами, а й демонструвати зміни, адже це сприятиме утвердженню відкритості та здобуттю довіри серед 
споживачів. Відповідно онлайн-середовище дає багато можливостей для цього [16]. Також доцільно, щоб компанії впроваджували інновації в способах комунікації зі своїми клієнтами і освоювали нові канали продажів. До таких каналів належать: комунікація у месенджерах, особливі умови за доставки продукції (бонуси, знижки), розвиток онлайн-продажів, онлайн-комунікації, консультації телефоном, віддалені консультації, sms-розсилки, радіореклама, відеопідтримка, відеопродажі, відеопрезентації.

Висновки і перспективи подальших досліджень. Таким чином, у статті досліджено останні тенденції споживчої поведінки в умовах пандемії COVID-19. Виокремлено етапи переходу компаній до комунікацій зі споживачами в цифровому середовищі. Наведена коротка статистика щодо світового споживання продуктів різних сфрер, зокрема виявлена позитивна динаміка в зростанні кількості пошукових запитів користувачів Інтернету щодо покупки продукції в сфрері здоров'я. Науковці визначили основні тренди в інтернет-маркетингу останніх років та, ґрунтуючись на них, сформували рекомендації щодо наповненості маркетинговими інструментами майбутніх стратегій компаній у цифровому середовищі в середньостроковій перспективі, а саме: розроблення якісного онлайн-контенту, врахування особливостей інформаційного простору цільової аудиторії, роботу з відгуками споживачів, впровадження інноваційних способів комунікації з клієнтами.

Перспективи подальших досліджень. У подальших дослідженнях доречно акцентувати увагу на кількісних маркетингових дослідженнях щодо ставлення споживачів до сучасних продуктових пропозицій компаній та їхньої готовності співпрацювати з ними в рамках маркетингових програм з метою удосконалення форм маркетингової взаємодії з наявними та потенційними клієнтами.

\section{תimepamypa}

1. Гузунова Ю. Тест на прозрачность: потребитель установил новые правила. URL: https://mmr.ua/show/test_na_prozrachnosty_potrebitely_ustanovil_novye_ pravila (дата звернення 25.05.2021).

2. PWC. Підготовка до роботи з новим поколінням споживачів уже сьогодні: майбутнє споживчих ринків. URL: https://www.pwc.com/ua/uk/survey/2021/futureof-consumer-markets-ukr.pdf (дата звернення 29.05.2021).

3. Небилиця О. А. Особливості інтернет-маркетингу підприємств в умовах пандемії. Тези доп. V Наук.-практ. конф. «Економічний розвиток і спадщина Семеня Кузнеия» (26-27 листоп., 2020 р.). - Одеса : Видав. дім «Гельветика», 2020. C. $106-107$.

4. Латишев К. О., Герасимчук В. В. Маркетинг цифрової сфери: поведінка споживачів в умовах пандемії. Економічний простір. 2020. № 160. С. 82-85.

5. Вовчанська О. М., Іванова Л. О. Інструменти маркетингових комунікацій під час пандемії COVID-19. Scientific collection «Interconf». C. 149-156. URL: https:// ojs.ukrlogos.in.ua/index.php/interconf/article/view/9291/9000 (дата звернення 01.06.2021).

6. Боровик Л. В. Значимість інформаційних технологій у розвитку економіки підприємства у період пост пандемії. Економіка та підприємництво. 2020. № 45. C. 83-92. 
7. Проскруніна Н. В. Трансформація маркетингової діяльності підприємств роздрібної торгівлі в умовах цифровізації : автореф. дис. ... д-ра екон. наук ; Харків : Харківський держ. ун-т харчування та торгівлі. 37 с.

8. Андрушкевич 3. М., Нянько В. М., Сітарчук О. В. Діджиталізація - дієвий інструмент комунікативної політики підприємства в період пандемії COVID-19. Вісник Хмельницького нац. ун-ту. 2020. № 5. С. 15-18.

9. Boronos V., Zakharkin O., Zakharkina I., Bilous Y. The impact of the covid-19 pandemic on business activities in Ukraine. Health Economics and Management Review. 2020. № 1(1). P. 76-83. https://doi.org/10.21272/hem.2020.1-07.

10. Мельник Ю. М., Сагер Л. Ю., Черкас І. Ю. Трансформація маркетингових комунікацій: нетрадиційні види. Вісник Хмельницького нац. ун-ту. 2016. № 2. С. 164-168.

11. Сигида Л. О. Організаційно-економічний механізм управління маркетинговими каналами підприємства. Молодий вчений. 2017. № 10. С. 1048-1053.

12. Хоменко Л. М. Pinterest як сучасний маркетинговий інструмент в цифровій економіці. III Всеукр. наук.-практ. інтернет-конф. «Маркетинг в умовах розвитку цифрових технологій» : тези доп. IBВ Луцького НТУ, 2020. С. 208-211.

13. Goncarova Z., Pitekova J., Vrablikova M. Assessment of the Impact of Selected Satisfaction Parameters on the Competitiveness of Family Tourism. Marketing and Management of Innovations. 2020. № 4. P. 131-143. http://doi.org/10.21272/ mmi.2020.4-10.

14. Davidaviciene V., Meidute-Kavaliauskiene I., Paliulis R. Research on the Influence of Social Media on Generation Y Consumer Purchase Decisions. Marketing and Management of Innovations. 2019. № 4. P. 39-49. http://doi.org/10.21272/ mmi.2019.4-04.

15. Летуновська Н. Є. Соціальні інновації підприємств в умовах трансформаційної економіки. Інноваційна економіка. 2013. Вип. 4. С. 107-112.

16. Сигида Л. О., Сагер Л. Ю., Летуновська Н. Є. Формування стратегії випереджаючого інноваційного розвитку в умовах Індустрії 4.0. Економічний аналіз. 2019. Т. 29, Вип. 2. С. 53-61.

\section{References}

1. Guzunova Yu. Test na prozrachnost: potrebitel ustanovil novye pravila [Transparency test: the consumer has set new rules]. Retrieved from: https://mmr.ua/show/test_ na_prozrachnosty_potrebitely_ustanovil_novye_pravila [in Russian].

2. PWC. Pidhotovka do roboty z novym pokolinniam spozhyvachiv uzhe siogodni: maibutnie spozhyvchykh rynkiv [PWC. Preparing to work with a new generation of consumers today: the future of consumer markets]. Retrieved from: https://www. pwc.com/ua/uk/survey/2021/future-of-consumer-markets-ukr.pdf [in Ukrainian]].

3. Nebylytsia, O.A. (2020). Osoblyvosti internet-marketynhu pidryiemstv $v$ umovakh pandemii [Features of Internet marketing of enterprises in a pandemic]. Abstracts of the $V$ scientific-practical conference «Economic development and heritage of Semyon Kuznets» [in Ukrainian]. 
4. Latyshev, K.O., Herasymchuk, V.V. (2020). Marketynh tsyfrovoi sfery: povedinka spozyvachiv $v$ umovakh pandemii [Digital marketing: consumer behavior in a pandemic]. Ekonomichnyi prostir - Economic space, 160, $82-85$ [in Ukrainian].

5. Vovchanska, O.M., Ivanova, L.O. Instrumenty marketynhovykh komunikatsii pid chas pandemii COVID-19 [Marketing communication tools during the COVID-19 pandemic]. Scientific collection «Interconf». Retrieved from: https://ojs.ukrlogos. in.ua/index.php/interconf/article/view/9291/9000 [in Ukrainian].

6. Borovyk, L.V. (2020). Znachymist informatsiinykh technolohii u rozvutku ekonomiky pidpryiemstva u period post pandemii [The importance of information technology in the development of the economy of the enterprise in the post-pandemic period]. Ekonomika ta pidpryiemnytstvo - Economics and entrepreneurship, 45, 83-92 [in Ukrainian].

7. Proskrunina, N.V. (2021). Transformatsiia marketynhovoi diialnosti pidpryiemstv rozdribnoi torhivli $v$ umovakh tsyfrovizatsii [Transformation of marketing activity of retail trade enterprises in the conditions of digitalization]. Doctoral theses. Kharkiv: Kharkiv State University of Food and Trade [in Ukrainian].

8. Andrushkevych, Z.M., Nianko, V.M., Sitarchuk, O.V. (2020). Didzytalizatsiia - diievyi instrument komunikatyvnoi polityky pidpryiemstva v period pandemii COVID-19 [Digitalization is an effective tool of enterprise communication policy during the COVID-19 pandemic]. Visnyk Khmelnytsoho natsionalnoho universytetu - Bulletin of Khmelnytsky National University, 5, 15-18 [in Ukrainian].

9. Boronos, V., Zakharkin, O., Zakharkina, I., Bilous Y. (2020). The impact of the covid-19 pandemic on business activities in Ukraine. Health Economics and Management Review, 1(1), 76-83. https://doi.org/10.21272/hem.2020.1-07 [in English].

10. Melnyk, Yu.M., Saher L.Yu., Cherkas, I.Yu. (2016). Transformatsiia marketnhovykh komunikatsii: netradytsiini vydy [Transformation of marketing communications: nontraditional types]. Viznyk Kmelnytskoho natsionalnoho universytetu - Bulletin of Khmelnytsky National University, 2, 164-168 [in Ukrainian].

11. Syhyda, L.O. (2017). Orhanizatsiino-ekonomichnyi mekhanizm uppravlinnia marketynhovymy kanalamy pidpryiemstva [Organizational and economic mechanism of management of marketing channels of the enterprise]. Molodyi vchenyi - A young scientist, 10, 1048-1053 [in Ukrainian].

12. Khomenko, L.M. (2020). Pinterest yak suchasnyi marketynhovii instrument v tsyfrovii ekonomitsi [Pinterest as a modern marketing tool in the digital economy]. III All-Ukrainian scientific-practical Internet conference «Marketing in the context of digital technology development». Lutsk [in Ukrainian].

13. Goncarova, Z., Pitekova, J., Vrablikova, M. (2020). Assessment of the Impact of Selected Satisfaction Parameters on the Competitiveness of Family Tourism. Marketing and Management of Innovations, 4, 131-143. http://doi.org/10.21272/ mmi.2020.4-10 [in English].

14. Davidaviciene V., Meidute-Kavaliauskiene, I., Paliulis, R. (2019). Research on the Influence of Social Media on Generation Y Consumer Purchase Decisions. Marketing and Management of Innovations, 4, 39-49. http://doi.org/10.21272/ mmi.2019.4-04 [in English]. 
15. Letunovska, N.Y. (2013). Sotsialni innovatsii pidpryiemstv v umovakh transformatsiinoi ekonomiky [Social innovations of enterprises in a transformational economy]. Innovatsiina ekonomika - Innovative economy, 4, 107-112 [in Ukrainian].

16. Syhyda, L.O., Saher, L.Yu., Letunovska N.Ye. (2019). Formuvannia stratehii vyperedzhaiuchoho innovatsiinoho rozvytku v umovakh Industrii 4.0 [Formation of a strategy of advanced innovation development in the conditions of Industry 4.0]. Ekonomichnyi analiz - Economic analysis, 29(2), 53-61 [in Ukrainian].

Статтю отримано 5 липня 2021 р.

Article received July 5, 2021 